\title{
MULTILATERAL TRADING PLATFORM IN EUROPE AND HUNGARY ${ }^{1}$
}

\author{
Krisztián Klis - Ágnes Vidovics-Dancs
}

First, we present the development of multilateral trading platforms through international examples in our study. In connection with this topic, we describe and compare three already operating multilateral trading markets (the Polish, English and Scandinavian markets). We present the economic and legal background of the Hungarian market and summarise the challenges the domestic SME sector has to face in terms of fundraising. Later, we introduce the participants and the operation of the multilateral trading market through the Hungarian example known as BSE Xtend.

JEL codes: $\mathrm{G}_{1}, \mathrm{G}_{2}, \mathrm{G}_{3}$

Keywords: multilateral trading system, BSE Xtend, small and medium-sized enterprises

\section{MULTILATERAL TRADING SYSTEM}

The term multilateral trading system comes from the term Multilateral Trading Facility (hereinafter referred to as MTF). The term first appeared in an EU Directive known as MiFID in 2004, defined as follows: "a multilateral system operated by an investment firm or market operator, which brings together multiple thirdparty buying and selling interests in financial instruments - in the system, in accordance with non-discretionary rules - in a way that results in a contract" (EU, 2004, 4/15).

Based on the above, MTF is an electronic trading system that facilitates the exchange of financial instruments. According to regulations in the USA and Canada, the term Alternative Trading System (ATS) refers to similar platforms ${ }^{2}$. In fact, these MTF platforms could be called the "little brother" of the stock exchange, as they usually enable entering the market and being present in the market under

1 We would like to thank István Máté-Tóth, Deputy CEO of the Budapest Stock Exchange, responsible for trading and business development, as well as Márton Paulovits, Director at Issuers Acquisitions Directorate at the Budapest Stock Exchange for their persistent and helpful work.

2 The two terms are often used as synonyms. 
cheaper and more favourable conditions. Sometimes, it is difficult to distinguish the two trading venues, as stock markets are allowed to operate an MTF (and they do in many cases), but enterprises engaged in investment activity are entitled to operate only MFTs, but not a stock exchange.

Even though the term MTF was codified only by the MiFID Directive, MTF markets have existed for decades. The most famous and successful ones are the following: Alternative Investment Market (hereinafter referred to as AIM, the UK, 1995), TSX Venture Exchange (Canada, 1999), Nasdaq First North (Scandinavian countries, 2005), NewConnect (Poland, 2007) and ChiNext (China, 2009).

Although the size of European MTF markets still does not reach that of traditional stock markets, in August 2018, the turnover of European premium stock markets amounted to nearly EUR 800 billion, while that of MTF markets was EUR 6.5 billion; it is worth studying such markets. Since 2017, there has been an MTF market even in Hungary. Under the name of BSE Xtend, it enables developed SMEs to enter the stock market under favourable conditions.

In Chapter 3, we explain in detail the structure of an MTF market through the Hungarian example. In order to put it into context, we shortly describe three European (Polish, Scandinavian and English) alternative trading platforms, providing some insight into the emergence and development of these European markets. The common feature of these markets is that they seek to provide SMEs with public markets which work similarly to traditional, regulated stock markets, however, offer more favourable terms to new issuers who enter the markets. Such conditions are detailed in Chapters 4 and 5.

Polish MTF market NewConnect was set up by the Warsaw Stock Exchange on 30 August 2007 for small and medium-sized enterprises with high growth potential. When establishing NewConnect, AIM, a London-based MTF market, served as an example. NewConnect aimed to provide a realistic alternative to fundraising in the stock market in the SME sector. Technically, this market is regulated similarly to traditional stock markets, however, the criteria for market access and trading are not so strict, and the fees are more favourable (Asyngier, 2014). After the dynamic growth of the initial years, about 400 companies have been introduced to NewConnect over the past few years (see: Figure 1). 
Figure 1

The number of companies registered in the NewConnect market (2007-2018)

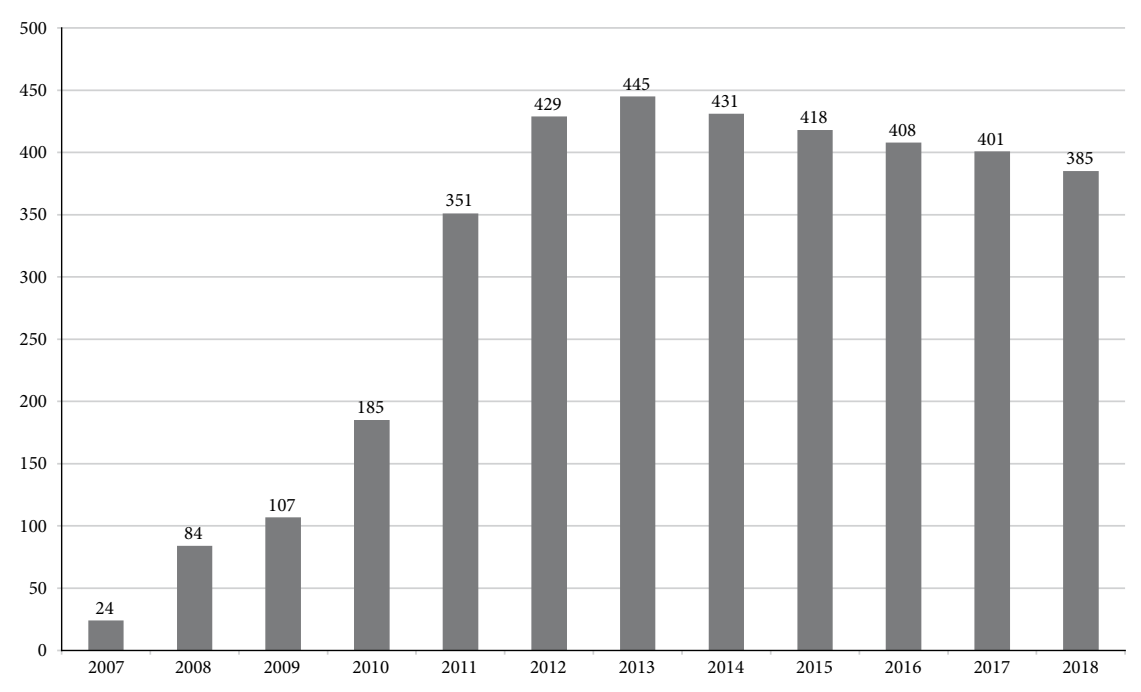

Source: a figure edited by the authors

Data source: NewConnect (2019a)

Nasdaq First North, a multilateral trading system, was launched in Denmark in 2005. In 2006, it was bought up by the Swedish stock exchange, Nasdaq Nordic, therefore its headquarters were relocated to Stockholm. Currently, the structure referred to as the Scandinavian MTF market includes the Danish, Swedish, Lithuanian, Latvian, Armenian and (since 2006) the Finnish and Icelandic capital markets. (Nasdaq OMX Nordic, 2018). In addition to the English and Polish MTF markets, Nasdaq First North is one of the most dynamically developing SME markets of Europe. In May 2019, it had 580 registered companies (Nasdaq First North (2019a).

The London-based Alternative Investment Market, which was established in 1995 , is one of the oldest MTF markets. AIM, which started only with 10 companies, had already 121 registered enterprises at the end of the year of its foundation. Currently, it is the largest and most successful SME market in the world (London Stock Exchange, 2018a). Figure 2 shows the number of participants entering the AIM market per year. Until the spill-over effect of the crisis of 2008, the number of new companies entering the AIM had been dynamically increasing, reaching its peak between 2005 and 2006. Although the crisis slowed down the growth of the AIM, on average 65 British small and medium-sized companies and 21 SMEs 
of other nationality have entered this market since then. Based on data from 2018, 942 enterprises out of the 2168 companies of the London premium stock exchange were registered on the MTF market (London Stock Exchange, 2019a).

\section{Figure 2}

The number of new companies in the AIM market (2007-2018)

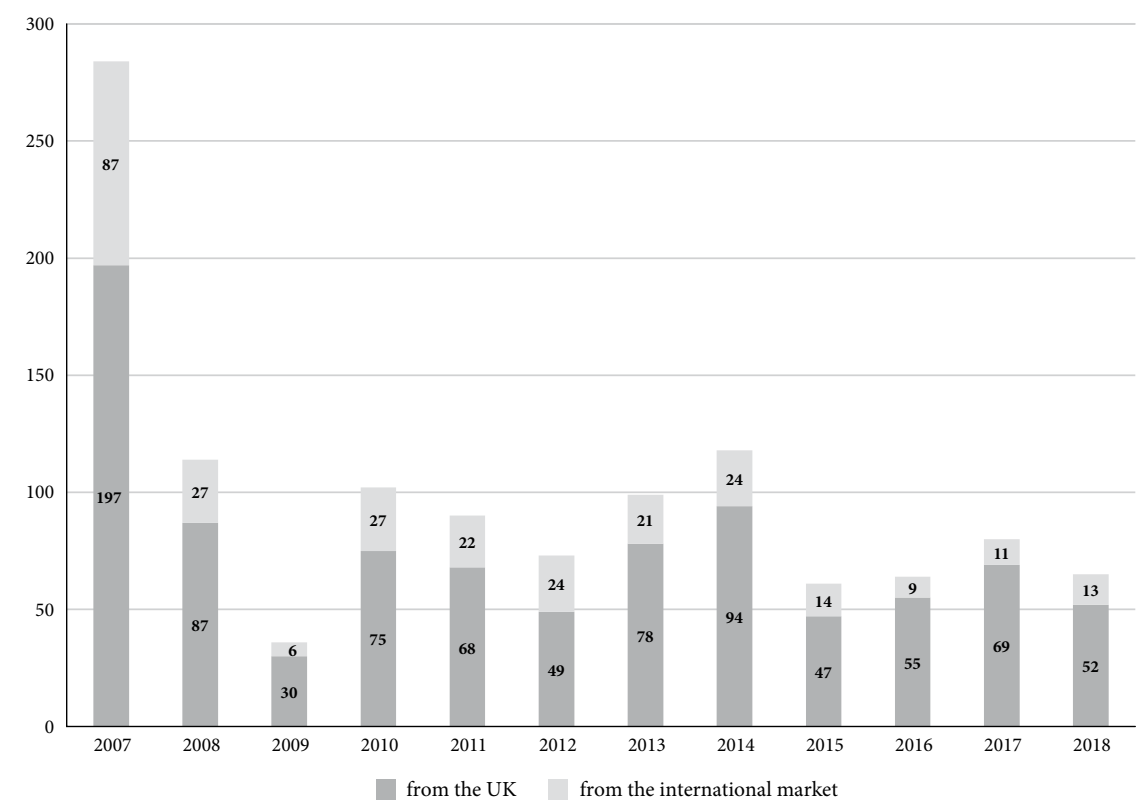

Source: a picture edited by the authors

Data source: (London Stock Exchange, 2019a)

The fact that the London Stock Exchange became a major shareholder in Turquoise in February 2010 played a key role in the success of the AIM. Turquoise had been the largest multilateral trading system in Europe. It has a wide European clientele, including emerging markets, inter alia Hungary and the Czech Republic. As a result, it can trade stocks, depositary receipts, exchange traded funds (ETF) of 19 European member countries, as well as the European options of the same number of countries. The members include banks, brokers, stockists and retail intermediaries (London Stock Exchange, 2018b).

Currently, the London Stock Exchange is expanding its Real Time Data service in Asia (London Stock Exchange, 2018c). Since 1 October 2018, Asian retail investors can have access to the real time data of the London Stock Exchange through eight licensed traders. The RealTimeData service provides investors with valuable information on securities listed and traded on the stock exchange, including 
the London Stock Exchange and the Borsa Italiana. According to Simon Youdan, Business Development Executive of the London Stock Exchange, the Asian continent is a strategically important territory for the London Stock Exchange, as real-time access to high quality data is essential for those who seek to achieve high exposure to global markets and support the platform with their trading activity (London Stock Exchange, 2018c).

In conclusion, Turquoise, which is currently owned by AIM, is the largest MTF platform in Europe, where the stocks of companies are traded. Upon the independent initiative of the Budapest Stock Exchange, an MTF market has been established in Hungary, as well. BSE Xtend is to trade the shares of small and medium-sized enterprises. In the next chapter, we describe why we believe that the introduction of MTF markets is essential in connection with the financing of SMEs.

\section{SMALL AND MEDIUM-SIZED ENTERPRISES AND THE MTF}

Small and medium-sized enterprises face several challenges in the course of their operation. They have to tackle different external and internal factors to maintain and increase their profitability in the long run or to survive. According to Kállay (2012) and Vágány-Kárpátiné-Daróczi (2011), the main challenges SMEs have to confront are the following:

- Dependency: Small and medium-sized enterprises depend much more on buyers and suppliers than large multinational companies. SMEs are less frequently considered as strategic partners of high priority, which can be important, for example, during a negotiation about granting a respite for payment.

- Low capital supply: Small and medium-sized enterprises often do not have enough equity and/or have liquidity problems.

- Funding difficulties: In many cases, it is more difficult for SMEs to obtain external resources (either equity or debt). When taking out a loan, they are usually considered to be risky clients, and face higher interest rates and transaction costs.

- Low risk-bearing ability: SMEs cannot take risks or bear to be loss-making for several years.

- Tax burden. According to Kállay (2012), bigger companies have to pay lower taxes.

In our study, we focus on funding difficulties. The establishment and operation of businesses require capital. SMEs may need to raise funds in order to develop human resources (hire more employees, train their existing employees and hire 
more qualified workforce) or promote innovation (introduction of new technology), with the usual aim of maintaining or increasing their market share: financing situation is a factor of competitiveness. Table 1 summarises the most important forms of corporate funding. ${ }^{3}$

\section{Table 1}

Corporate financing facilities

\begin{tabular}{ccc}
\hline & INTERNAL FUNDING & EXTERNAL FUNDING \\
\hline & $\begin{array}{c}\text { Reinvestment of profit } \\
\text { Amortisation } \\
\text { Transfer of assets }\end{array}$ & Owners' equity \\
& & \\
& & Bank loan \\
& & Bond issue \\
& Leasing \\
& & Supplier loan \\
& Factoring \\
\hline
\end{tabular}

Source: Table edited by the authors, based on the description of Vasné (2006)

In the case of internal financing, the company provides the required resources without external help, while in the case of external funding, its capital requirement is satisfied from external sources, by borrowing from owners or creditors. Public companies can increase capital on the stock market or MTF market by means of public share offering.

Several countries face the problem of the economy not being able to exploit the potential of SMEs due to their low or structurally not appropriate funding. In the annual publication of the London Stock Exchange Group on SMEs (London Stock Exchange Group, 2017), financial and economic leaders (such as Toomas Töniste, the Estonian Minister of Finance or Roberto Gualteri, Chair of the Economic and Monetary Affairs Committee of the European Parliament unanimously state that the SME sector constitutes the backbone of the economy and is key for growth, innovation and job creation in Europe. At the same time, it is often mentioned (for example, by Xavier Rolet, the CEO of the London Stock Exchange in the same publication) that traditional forms of funding (typically loans) are not suitable for

3 The collection cannot be called taxative and does not include the so-called mezzanine financing forms at all. 
the financing of this sector, which would rather require equity-based resources, however, in a more flexible form. In fact, the history of SMEs and the development of MTF markets meet at this point. Several MTF markets were specifically established to provide a financing platform for this sector.

The most important feature of the platform is that the SMEs with special growth and innovation potential, which intend to get funding to develop their product or service, issue the company's shares on an MTF, a so-called secondary stock exchange. They do so because they are still not ready to enter the primary stock exchange, owing to the introduction requirements.

The funding of Hungarian small and medium-sized enterprises is dominated by domestic loans and EU grants (HCSO, 2017). After the crisis, the loan volume accumulated over the previous years was dynamically decreased, and then it has been growing again since 2015. According the assessment published by the National Bank of Hungary in 2017, the Funding for Growth Scheme (FGS) largely contributed to the turn, as after its launch in 2013, "the credit institutions participating in the programme concluded contracts amounting to HUF 2811 billion with 39254 micro-, small and medium-sized enterprises" (MNB, 2017, p. 2). Being listed on the stock exchange is not typical of this sector, though stock market capitalisation cannot be called high in Hungary anyway, as based on the 2018 data of the Global Economy, it made up 22.68\% of the GDP (The Global Economy, 2018).

Over the past decade, venture capital funds have spread in Hungary, as well, providing an opportunity for SMEs to obtain resources, however, sometimes with such conditions that the enterprises are not willing to fulfil, for example, they do not want to assign rights of ownership and control to the financer.

\section{CHARACTERISTICS OF THE BSE XTEND MARKET}

The most important goals of the Budapest Stock Exchange are to promote the development of the capital market, promote its international competitiveness, ensure its transparent operation, increase and protect the security of investments and expand the opportunities for capital market participant to obtain funds. In view of the above, the Budapest Stock Exchange opened its first multilateral trading system called BSE Xtend in September 2017. Xtend provides opportunities for small and medium-sized enterprises which are planning significant business growth, looking for external financing and are able to fulfil the requirements of the multilateral trading market to enter the capital market and obtain funds. The companies which the Budapest Stock Exchange intends to list on the MTF market "are able to enrich the range of stocks traded in the BSE, evoke the interest of potential investors with new investment stories and their dedicated business ideas 
and, of course, imagine their future in the capital market in the long run" (BSE, 2018b, p. 1).

The companies entering the domestic MTF market face lower fees and less complicated terms, and they also receive special supporters, but under regulated conditions that are similar to traditional stock markets (BSE (2018c). The easier conditions enable them to get used to transparency in the stock market gradually while being able to enter the stock market in a category as "appreciated" as bigger companies. According to Richárd Végh, the President CEO of the Budapest Stock Exchange, the long-term goal of the BSE is to ensure that developed SMEs can develop into professional corporations operating transparently with the support of the BSE (Végh, 2016).

The specialty of Xtend and MTF markets in general is that the enterprise issuing shares in such markets is connected with a group of investors, usually called investor pool, by a nominated advisor. Figure 3 schematically presents the relationships between the participants.

\section{Figure 3}

The structure and contact network of the MTF market

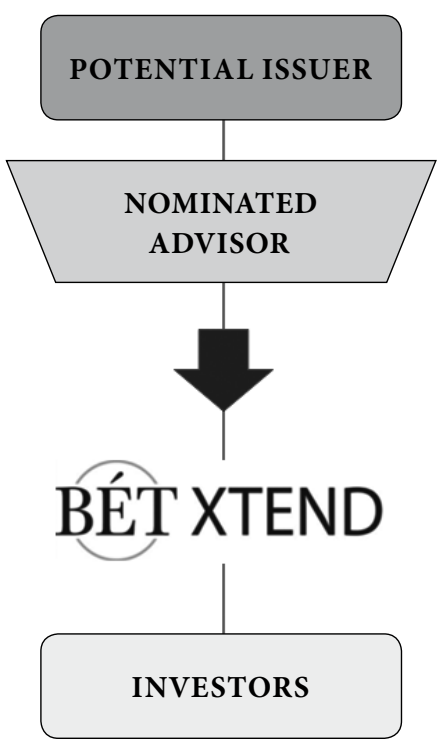

Source: edited by the authors 
One of the most important participants of the multilateral trading market is the issuer, i.e. the small and medium-sized enterprise entering the market. The operation of the MTF market is determined by the potential group of investors (the socalled investor pool) from where the issuers can obtain capital and funds in the in long run. The contact between potential investors and the issuer is established by an important participant, the nominated advisor through the BSE Xtend platform. The nominated advisor continuously supports the issuer not only in entering the market, but also during its market presence, which is a kind of guarantee for the investors. Prior to entering the market, the nominated advisor screens the potential issuer, supports its preparation for the stock market, prepares and implements its capital market transactions. After the transactions, the nominated advisor supports the public operation of the issuer and makes annual declarations on the compliance of the Xtend market with the policy. The regulatory framework of the BSE Xtend market was established by the BSE. Market surveillance is shared by BSE and the National Bank of Hungary. In this market, the BSE is also responsible for checking the information documents required for introduction and determining their content (below a total issue value of HUF 5 million) (BSE, 2018d).

\subsection{Potential issuers (developed small and medium-sized enterprises)}

Over the past decade, the lack of resources in the Hungarian SME sector has been significantly decreased by different EU sources. In this respect, there are several companies which have not been able to accumulate enough capital despite the Funding for Growth Scheme, which prevents the possibility of further development. In the long run, in a less favourable interest rate environment, in addition to loans, opportunities to obtain resources from the capital market are required, as well. The Xtend market, which can be considered the "hall of the stock market", makes such opportunities available for SMEs, as well, due to favourable conditions.

Based on the study of small and medium-sized enterprises in Polish, English and Scandinavian MTF markets, the stock market presence of SMEs is more common in the following industries: telecommunications, IT, software and computer industry, healthcare, financial services, as well as in the petroleum and natural gas industry (London Stock Exchange, 2019a; 2018d). These industries have dynamic development opportunities which can be attractive to capital market investors.

It is important both at international and national level that the companies which enter the stock market fulfil the high-level requirements of investor confidence, perform in a stable manner and have a business strategy that ensures growth po- 
tential. As a result, such companies can expect that investors will be seriously interested in them.

The registration of securities in the MTF market can take place in two ways: on the one hand, by initial public offering (IPO), on the other hand, by so-called technical introduction. Technical introduction is an excellent option for those companies which raise capital in a closed circle prior to introduction to the stock exchange and issue their shares after the capital increase. This public form of appearance is called technical introduction. IPO (Initial Public Offering) means that the shares of the company are sold to institutional investors. IPO is registered by the BSE with the approval of the National Bank of Hungary, introducing the company concerned officially to the stock exchange. Figure 4 shows the number of IPOs in the Polish, English and Scandinavian markets in 2017. If SMEs pursue a business strategy that complies with market conditions, they can enter the regulated premium or higher category market, as well (Tamborski, 2015).

\section{Figure 4}

The number of IPOs in some MTF markets in 2018

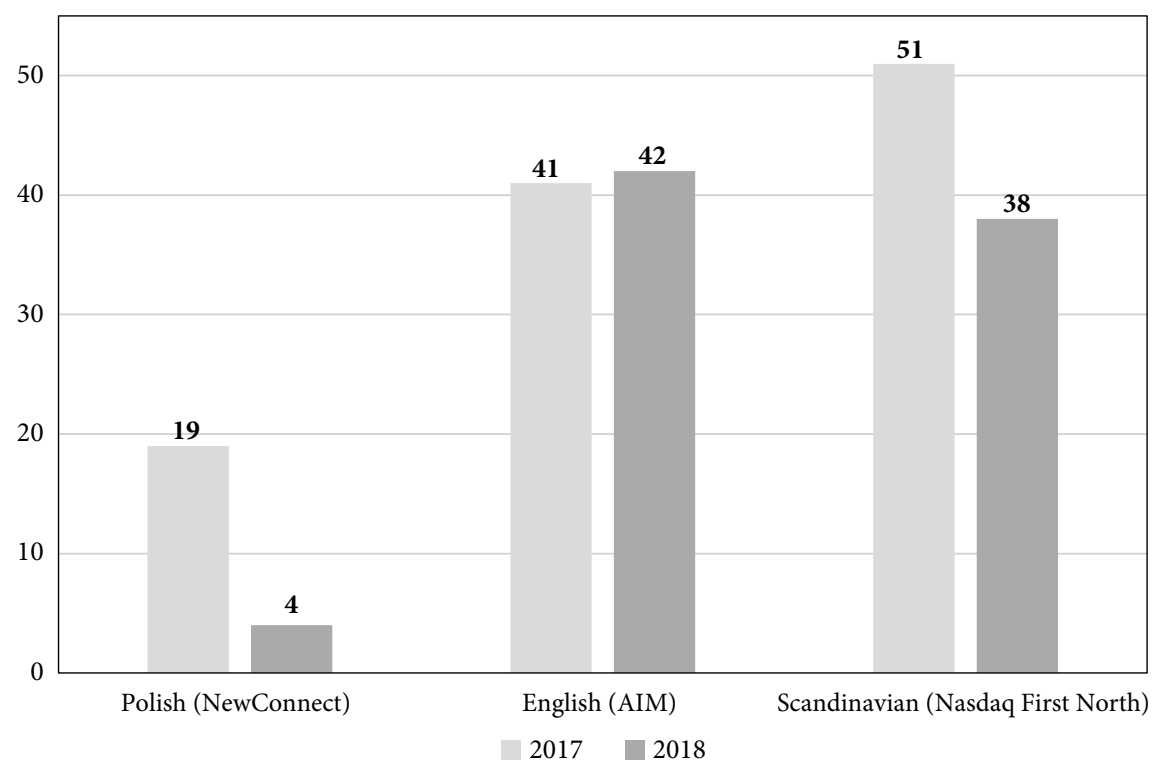

Source: edited by the authors

Data source: FESE (2019) and London Stock Exchange (2019b) 


\subsection{Nominated adviser}

One of the characteristics of multilateral trading markets is that several regulatory tasks were delegated from the local supervisory authorities (e.g., the $\mathrm{Na}$ tional Bank of Hungary) to the market operator (the Budapest Stock Exchange in Hungary). The stock exchange can act in a more flexible way when evaluating introduction requests, which accelerates the process. The administrative costs are also lower than in the regulated market (BSE, 2017). The different fees and costs are presented in Chapter 5 by comparing the leading MTF markets.

On the Xtend market, BSE and the National Bank of Hungary share the supervisory role. In order to promote the investors' interests in the most effective way and support the public operation of SMEs, most MTF markets require the long-term presence and participation of the nominated advisor. The nominated advisor has a dual function: on the one hand, he/she is a guarantee towards the investors; on the other hand, he/she provides support to the issuer (BSE, 2018e). The nominated advisor helps the preparation of the enterprise from the beginning of the introduction process, providing a kind of guarantee to investors concerning the reliability and preparedness of issuers on the MTF market. Based on an interview with Róbert Hrabovszki, a former chief advisor of OTP Bank, as opposed to the main market, on the MTF market, the advisor continuously supports the operation of the company even after its market entry. Based on international practice, two options exist regarding when and exactly how issuers shall be supported: (i) for a certain period after introduction, for example for 1 year; or (ii) during the whole period of trading (London Stock Exchange, 2018e).

The nominated advisor analyses and assesses the negotiability of the examined company and compiles the introductory documents, which contain the data of the company and the issue, in collaboration with the company. The introductory documents are sent to the operator of the market. The advisor shall make a declaration on whether the documentation fulfils the criteria set by the MTF. The advisor provides advice continuously in the course of the process of introduction and, if required, supports the management and the employees concerned with training (Peyrano, 2017).

If the listing requirements are fulfilled and the supervisory and market authorities have approved of the information document submitted by the issuer, the issuer will be introduced to the Xtend following the acceptance of the registration request. The circle of nominated advisors shall be determined by the BSE. A valid contract shall exist between the issuer and a nominated advisor accepted by the BSE, indicating the beginning of long-term cooperation. In 2018, officially 16 nominated advisors worked on the BSE Xtend market (BSE, 2018f). 


\subsection{Investor pool}

BSE Xtend is an online trading platform set up for SMEs. The investors on the demand side and a significant part of the capital provided by them are decisive regarding the success and activity of the MTF markets. Investors choose from available capital market options based on the following criteria: (i) potential to generate income, (ii) risks, (iii) investor expectations, (iv) time horizon of the investment, (v) the investor's willingness to take risks, (vi) alternative investment options (Chikán, 2008).

In Hungary, the main problem is the lack of investment culture. Unfortunately, the inappropriate knowledge of capital market risks and possibilities prevents the development of healthy investor demand and culture. In order to protect investors, the first Markets in Financial Instruments Directive (MiFID I) already introduced a compulsory professional compliance and (if needed) eligibility test for investors, the content requirements of which were further strengthened by MiFID II (EU, 2014). Pursuant to the aforementioned directive, only investors with appropriate financial and professional knowledge are allowed to trade on the stock market.

The National Stock Exchange Development Fund (NSEDF) provides a financial opportunity for those small and medium-sized enterprises which are "at the gate" of the stock exchange. The primary goal of the NSEDF is to ensure a smooth introduction to the MTF market (BSE, 2018f). Széchenyi Venture Capital Fund Management cPlc. (SZTA) is responsible for managing the National Stock Exchange Development Fund. Széchenyi and Irinyi Venture Capital Funds and the National Stock Exchange Development Fund provide equity funding for the whole Hungarian SME sector. (At the end of 2017, the Ministry of National Economy selected Széchenyi Venture Capital Fund Management cPlc. as the manager of the fund in the framework of an open tender). The NSEDF supports the entry of SMEs to the stock market with HUF 13 billion in total. The NSEDF provides capital for enterprises which undertake to enter the BSE Xtend in the near future. On the one hand, the fund manager strives to form a strong and well-balanced circle of investors. On the other hand, it intends to introduce about 4-8 small and medium-sized enterprises annually to the domestic multilateral trading platform (Origo, 2018). 
An important feature of the NSEDF is that it obtains private capital in the form of co-investment. ${ }^{4}$ The whole maturity of the fund is 12 years. The fund manager provides financial support amounting to HUF 13 billion, which usually means the investment of a sum of HUF 1 billion per enterprise. At the same time, it must be remarked that the allocation of money depends on the number of applicants. The amounts provided should be balanced. The sum provided by the fund covers the costs arising from the employment of financial advisors, the listing of the securities on the stock market, as well as the costs of financial and legal screening. It is important to note that NSEDF invests into private limited companies so that the given company can appear and start trading on the multilateral platform.

According to József Tóth, Transaction Executive of Széchenyi Venture Capital Fund Management cPlc., SMEs should not fear that the new joint owner will take over control of the company, as Széchenyi Venture Capital Fund Management is entitled to acquire a shareholding of no more than $49 \%$. Széchenyi Venture Capital Fund Management $\mathrm{cPl}$. would like to achieve that SMEs ensure their growth from their own resources instead of being targets of acquisition and export the largest possible volume of products.

\section{BENEFITS OF THE BSE XTEND MARKET}

As international examples show, over the past few years, there has been a new opportunity for small and medium-sized enterprises in the field of equity financing: SMEs can obtain resources through different venture capital funds. At the same time, in the market, there are a lot of small and medium-sized enterprises which are reluctant to involve owners who would like to play an active role in the everyday operation of the company. "Public operation enables the company to create a more varied investor structure in the course of raising capital and give over the control arising from ownership to new investors only to an extent determined by the company" (BSE, 2018a, p. 1.). The following list compiled by the BSE (2018g) indicates the opportunities provided by BSE Xtend.

\section{1) Fundraising}

Public share offering may increase the freedom for financing for the issuer, therefore the enterprise concerned can develop more dynamically. In addition

4 In this case, Széchenyi Venture Capital Fund Management cPlc. as a private investor provides financial support directly to an operating company. It can be said that Széchenyi Venture Capital Fund Management cPlc. appears as a co-investor in the enterprise concerned. 
to equity financing, the offering may also be financed from loans under more favourable conditions. The following example illustrates this.

The first issuer of the Xtend market was Megakrán Plc. in 2018. MKB Bank cPlc. was involved in the offering as a nominated advisor. Megakrán started as a one-man business specialised in lifting technology in 1994. In the period following the crisis, the company was financed through the Funding for Growth Scheme, by means of which the company modernised all of its machinery. Figure 5 shows the annual change in the revenue and EBITDA of Megakrán. In 2015, the company's annual EBITDA of HUF 404 million resulted in the company's recovery from the crisis. Subsequently, the company's turnover grew by $15-20 \%$. As a result, its revenue reached a level of almost HUF 1800 million and its EBITDA indicator also peaked at a historic value of HUF 650 million in 2016. Megakrán entered the Xtend market in 2018, raising capital to finance its developments.

\section{Figure 5}

Revenue and EBITDA figures of Megakrán Plc. between 2015 and 2018

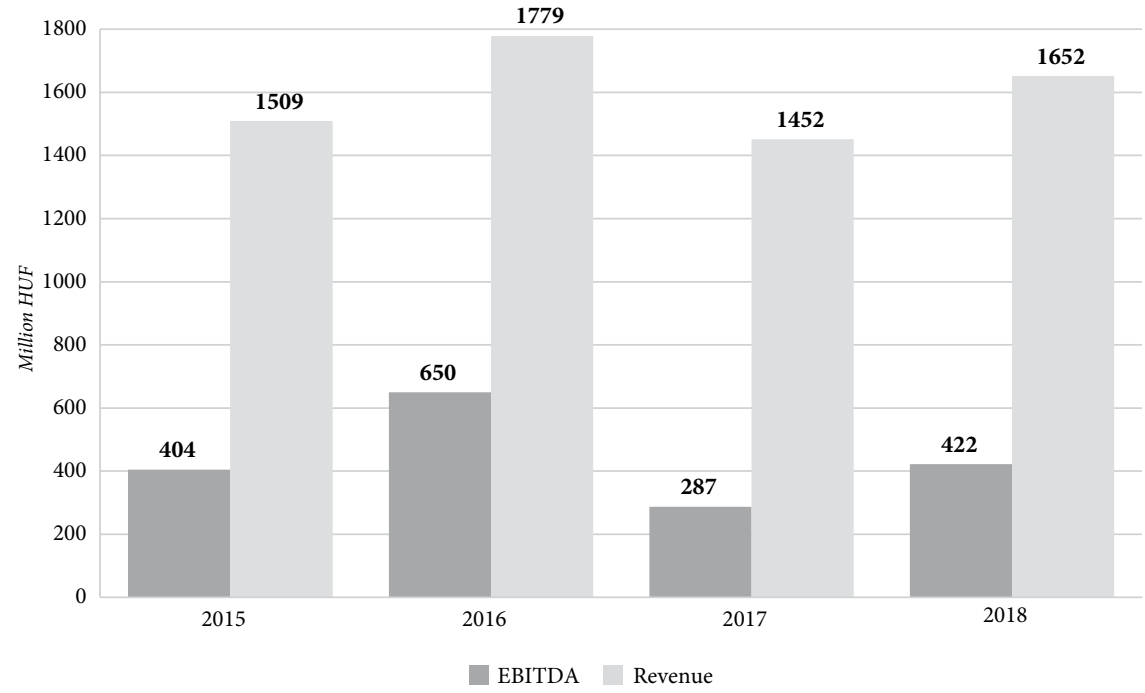

Source: edited by the authors

Data source: BSE50 (2018) and e-report (2019) 
The high increase proves the success of the realised investment projects. Due to the increased number of orders, the company arrived at another important milestone: a larger capacity building investment that could not be financed only from bank loans. Therefore, the company was one of the first enterprises which joined the Mentoring Programme of the BSE Xtend market. In 2018, the company's EBITDA indicator increased again; however, the effect of the company's entry to the MTF market can be assessed only in the long run.

2) The motivation of employees and managers

If the company concerned has an affiliate or a foreign partner, the acquisition of stock option is an important motivating factor.

3) Image or brand building

A company's listing on the stock exchange strengthens the brand name. Partners are more willing to do business with a better-known company. An excellent example of this is Dunahouse, a renowned domestic real estate agent.

4) More favourable loan conditions

The confidence of credit institutions (banks) in the company will be stronger. The company will be able to take higher amount of loans with more favourable conditions.

5) Retaining control

Realising the built-up value, i.e. retaining control within the company despite selling a part of it. The aim is to retain control rights in the hands of owners/ executives even after entering the stock market.

6) Publicity

The operation, revenue and earnings after taxes of a company on the stock market are publicly available to the company's foreign and domestic partners. The publicly available business data increase the confidence of the company's business partners as well as its business opportunities.

\section{7) Confidence}

Presence on the stock exchange reassures buyers, evokes the feeling of security and confidence. Another good example is a company called UBM, whose daily turnover of securities is almost zero, but it is still on the stock exchange. Despite being illiquid in the market, the company enjoys the benefits provided by the exchange. Partner companies, supplier and buyers have more confidence in such enterprises and invest more money in them. 


\section{THE FEES OF BSE XTEND}

\section{AND INTERNATIONAL MULTILATERAL MARKETS}

By presenting the fees of English, Polish, Scandinavian and Hungarian MTF markets, we aim to provide the reader with an extensive overview of the current costs small and medium-sized enterprises have to consider in both domestic and international markets. Figure 6 explains these costs, showing the comparison of the fees to be paid on the Hungarian BSE Xtend with the fees of NewConnect (Polish), London AIM Stock Exchange (English) and Nasdaq First North (Scandinavian) MTF markets.

\section{Figure 6}

\section{Comparison of the costs of MTF markets (in thousand HUF)}

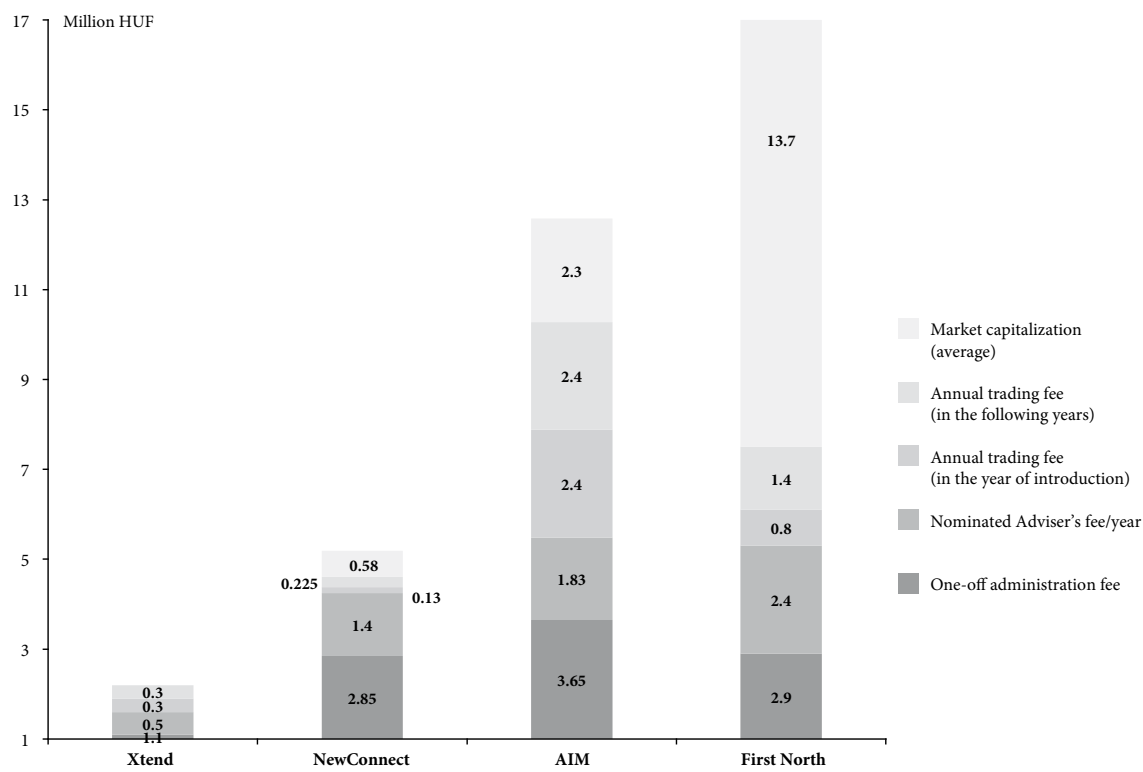

Source: edited by the authors

Data sources: (BSE, 2019; London Stock Exchange, 2019c; Nasdaq First North, 2019b; NewConnect, 2019b).

The costs related to multilateral markets not denominated in Hungarian currency were exchanged to HUF at a rate valid on 4 February 2019. ${ }^{5}$ Out of the cost elements, the market capitalisation fee needs some explanation. On the aforemen-

$51 \mathrm{EUR}=319 \mathrm{HUF}, 1 \mathrm{GBP}=365 \mathrm{HUF}, 1 \mathrm{PLN}=75 \mathrm{HUF}, 1 \mathrm{USD}=279 \mathrm{HUF}$ 
tioned markets, different capitalisation categories or "bands" are determined. The fee is based on the market capitalisation average of the months of the year, which means that the monthly capitalisations of the companies in the given market are quantified and averaged. ${ }^{6}$ The method for the calculation of the fee is different in each country. Its amount depends on which band the average capitalisation of the given MTF falls (London Stock Exchange, 2019c; Nasdaq First North, 2019b; NewConnect, 2019b). The annual fee of market capitalisation is not reimbursed even if a company is removed from or leaves the MTF market in a given year.

Picture 6 shows that the Scandinavian Nasdaq First North market has the highest fee. A small or medium-sized enterprise has to pay HUF 21.2 million $(2.9+2.4+0.8+1.4+13.7)$ on the Nasdaq First North market, taking into account the year 2018 in the case of market capitalisation and the year 2019 in the case of all other fees (Nasdaq First North, 2019b). AIM in London, the market with the longest history, is ranked second. SMEs have to pay an average annual fee of $\boldsymbol{H U F}$ 12.58 million on the AIM (London Stock Exchange, 2019c), while "only" HUF 5.19 million on NewConnect (NewConnect, 2019b). The administration fee, the fee of the nominated advisor and the annual trading fee amount to HUF 2.2 million on the BSE Xtend market. No data on market capitalisation are available yet, as trading started on 4 December 2018.

\section{SUMMARY}

In our study, we collected the benefits of joining a multilateral trading market and fulfilling the entry requirements in the SME sector. We presented the history of the development of the English, Polish and Scandinavian multilateral markets, which have been operating for several years and compared the stock market fees of the domestic BSE Xtend market with those of international markets.

6 Whether this year corresponds with the calendar year can be different in each market. 


\section{REFERENCES}

AsyngieR, R. (2014): NewConnect in comparison with multilateral trading facilities in Europe. Irregularities in the functioning of the Polish MTF market. Annales Universitatis Mariae Curie-Skłodowska, XLVIII(1), Lublin, p. 10-17. http://bazhum.muzhp.pl/media//files/Annales_Universitatis_Mariae_Curie_Sklodowska_Sectio_H_Oeconomia/ Annales_Universitatis_Mariae_Curie_Sklodowska_Sectio_H_Oeconomia-r2014-t 48 -n1/Annales_Universitatis_Mariae_Curie_Sklodowska_Sectio_H_Oeconomia-r2014-t 48 -n1-s9-23/ Annales_Universitatis_Mariae_Curie_Sklodowska_Sectio_H_Oeconomia-r2014-t48-n1s9-23.pdf, https://doi.org/10.17951/h.2014.48.1.9 (downloaded on 06.12.2018).

BSE (2017): Calibrated to medium-sized companies [BÉT Xtend - Középvállalatokra kalibrálva]. Budapest, https://www.bet.hu/pfile/file?path=/site/Magyar/Dokumentumok/Kibocsatok/Xtend/ BET-Xtend-leporello-press.pdf (downloaded on 10.03.2018).

BSE (2018a): Benefits of the BSE Xtend Market [Előnyök a BÉT Xtend piacon]. Budapest, https:// www.bet.hu/Kibocsatok/kozepvallalati-szolgaltatasok/xtend/Elonyok-a-BET-Xtend piacon (downloaded on 03.03.2018).

BSE (2018b): Life in the Xtend Market [Élet az Xtend-en]. Budapest, https://www.bet.hu/Kibocsatok/ kozepvallalati-szolgaltatasok/xtend/Elet-az-Xtend-en (downloaded on 02.03.2018).

BSE (2018c): Policies [Szabályzatok]. Budapest, https://www.bet.hu/Kibocsatok/kozepvallalati-szolgaltatasok/xtend/Szabalyzatok (downloaded on 02.03.2018).

BSE (2018d): Xtend Compared with Other Stock Exchange Categories [Xtend szemben az egyéb tőzsdei kategóriákkal]. Budapest, https://www.bet.hu/Kibocsatok/kozepvallalati-szolgaltatasok/xtend/Xtend-szemben-az-egyeb-tozsdei-kategoriakkal (downloaded on 02.03.2018).

BSE (2018e): Who are the Nominated Advisers? [Kik a kijelölt tanácsadók?] Budapest, https://www. bet.hu/Kibocsatok/kozepvallalati-szolgaltatasok/xtend/Kik-a-kijelolt-tanacsadok (downloaded on 03.03.2018).

BSE (2018f): National Stock Exchange Development Fund [Nemzeti Tőzsdefejlesztési Alap]. Budapest, https://www.bet.hu/Kibocsatok/kozepvallalati-szolgaltatasok/nemzeti-tozsdefejlesztesialap (downloaded on 03.03.2018).

BSE (2018g): Opportunity for Medium-Sized Enterprises [Lehetőség a középvállalatoknak]. Budapest, https://www.bet.hu/Kibocsatok/kozepvallalati-szolgaltatasok/xtend/Lehetoseg-kozepvallalatoknak (downloaded on 2018.03.03.).

BSE (2019): Fees [Díjak]. Budapest, https://www.bet.hu/Kibocsatok/kozepvallalati-szolgaltatasok/ xtend/Tovabbi-fontos-tudnivalok (downloaded on 03.03.2019).

BSE 50 (2018): The Success Stories of 50 Domestic Companies [BÉT50 - Ötven hazai vállalat sikertörténete]. Budapest: BÉT, https://www.bet.hu/Kibocsatok/bet5o/2018/vallalatok/outon-a-tozsderemegakran-zrt (downloaded on 22.12.2018).

Chiкán, Attila (2008): Business Economics [Vállalatgazdaságtan]. 4th revised, extended edition. Budapest: Aula.

E-report (2019): Company Information and Electronic Company Registration Service Ministry of Justice [e-beszamolo], https://e-beszamolo.im.gov.hu/oldal/kereses_merleglista?f=ThkJU\%2bVc UZiGgz6iZOjENw\%3d\%3d\&so=1https://e-beszamolo.im.gov.hu/oldal/kereses_merleglista?f=T hkJU\%2bVcUZiGgz6iZOjENw\%3d\%3d\&so=1 (downloaded on 2019.04.29.).

EU (2004): MiFID I (Markets in Financial Instruments Directive I). Directive 2004/39/EC of the European Parliament and of the Council, https://eur-lex.europa.eu/legal-content/EN/ $\mathrm{TXT} /$ ? uri $=$ celex\%3A32004Loo39 (downloaded on 14.02.2018). 
EU (2014): MiFID II (Markets in Financial Instruments Directive II). Directive 2014/65/EC of the European Parliament and of the Council, https:/eur-lex.europa.eu/legal-content/HU/TXT/PD F/?uri=CELEX:32014Loo65\&from=EN (downloaded on 14.02.2018).

FESE (2019): IPO database. Federation of European Securities, https://fese.eu/statistics/ (downloaded on 28.04.2019).

KÁllay, LÁszló (2012): SME sector: Competitiveness, Job Creation, Restructuring [Kkv-szektor: versenyképesség, munkahelyteremtés, szerkezetátalakítás]. Working Paper, TM 58. Budapest: Corvinus University of Budapest, Institute of Business Economics, Competitiveness Research Centre, http://edok.lib.uni-corvinus.hu/458/1/TM58_Kallay.pdf (downloaded on 11.03.2018.).

HCSO (2017): The Characteristics of SMEs [A kis- és középvállalkozások jellemzői]. Central Statistical Office [Központi Statisztikai Hivatal], Budapest, http://www.ksh.hu/docs/hun/xftp/idoszaki/pdf/kkv17.pdf (downloaded on 16.12.2018).

London Stock Exchange Group (2017). 1000 Companies to Inspire Europe. https://www.lseg.com/ resources/100o-companies-inspire/2017-report-100o-companies-europe (downloaded on 16.03.2018).

London Stock Exchange (2018a): AIM. www.lseg.com/aim (downloaded on 26.02.2018).

London Stock Exchange (2018b): AIM Securities on Turquoise. https://www.lseg.com/turquoise/aim (downloaded on 26.07.2018).

London Stock Exchange (2018c): London Stock Exchange Group Expands Real Time Data Service in Asia. https://www.lseg.com/resources/media-centre/press-releases/london-stock-exchangegroup-expands-real-time-data-service-asia (downloaded on 26.07.2018).

London Stock Exchange (2018d): Identifies 1000 most dynamic SME's in Europe. https://www. lseg.com/resources/media-centre/press-releases/london-stock-exchange-group-identifies1000-most-dynamic-smes-europe (downloaded on 26.02.2018).

London Stock Exchange (2018e): London AIM Market Nominated Advisor. https://www.londonstockexchange.com/companies-and-advisors/aim/advisers/advisers.htm (downloaded on 26.02.2018).

London Stock Exchange (2019a): Historical AIM Statistics. https://www.londonstockexchange.com/ statistics/markets/aim/aim.htm (downloaded on 23.04.2019).

London Stock Exchange (2019b): New and Further Issues. htts://www.londonstockexchange.com/ statistics/new-issues-further-issues/new-issues-further-issues.htm (downloaded on 24.04.2019).

London Stock Exchange (2019c): Fees for companies and nominated advisers. https://www.londonstockexchange.com/companies-and-advisors/aim/publications/aim-fees-for-issuers-2019.pdf.

National Bank of Hungary (2017): Results of the Growth Loan Programme [A Növekedési Hitelprogram eredményei]. MNB, http://www.mnb.hu/letoltes/a-novekedesi-hitelprogram-eredmenyeihonlapra-20170613.pdf (downloaded on 24.03.2018).

Nasdaq First North (2019a): Companies Listed on Nasdaq First North. http://www.nasdaqomxnordic.com/shares/listed-companies/first-north (downloaded on 25.04.2019).

Nasdaq First North (2019b): Equity Issuers on Nasdaq First North. https://business.nasdaq.com/media/First-North-Price-List-2019_tcm5044-21010.pdf (downloaded on 06.03.2019).

Nasdaq OMX Nordic (2018): Nasdaq's story. https://business.nasdaq.com/discover/nasdaq-story/ index.html (downloaded on 06.03.2019).

NewConnect (2019a): NewConnect Statistics. https://newconnect.pl/statistics-periodic (downloaded on 06.03.2019).

NewConnect (2019b): Market data. https://newconnect.pl/market-data (downloaded on 26.04.2019). 
Origo (2018): A Széchenyi Tőkealap-kezelö lett a Nemzeti Tőzsdefejlesztési Alap kezelője. http:// www.uzletresz.hu/sikerek/20180103-a-szechenyi-tokealap-kezelo-lett-a-nemzeti-tozsdefejlesztesi-alap-kezeloje.html (downloaded on 16.03.2018).

Peyrano, Luca (2017): ELITE - Connecting companies with capital. BÉT, https://www.bet.hu/ Kibocsatok/kozepvallalati-szolgaltatasok/ELITE-program/ELITE-program (downloaded on 18.03.2018).

TAMborski, PaWel (2015): Summary of the activities of Poland's first alternative trading platform. NewConnect Report, Warsaw Stock Exchange, p. 4-22. http://docplayer.net/47463678-Newconnect-report-2015-summary-of-the-activities-of-poland-s-first-alternative-trading-platform. html (downloaded on 16.03.2018).

The Global Economy (2018): Stock market capitalization, percent of GDP - country rankings. https://www.theglobaleconomy.com/rankings/Stock_market_capitalization/ (downloaded on 17.03.2018).

Tóth József (2018): National Stock Exchange Development Fund (NSEDF) [Nemzeti Tőzsdefejlesztési Alap (NTfA)]. Conference lecture, BSE50 conference (20.09.2018), https://www.bet.hu/Kibocsatok/bet5o/2018/bet5o-kozepvallalatok-csucstalalkozoja-harmadszor-is.

VÁGÁNy Judit - KÁrpátiné Daróczi Judit (2011): The Challenges of the Global Economic Crisis and the Chances of Recovery for SMEs [A gazdasági világválság kihívásai és a kilábalás lehetőségei a kkv-k számára]. https://www.researchgate.net/publication/277140417_A_gazdasagi_vilagvalsag_kihivasai_es_a_kilabalas_lehetosegei_a_kkv-k_szamara (downloaded on 16.03.2018).

VASNÉ Botár Ágnes (2006): The Typical External Sources of Funding for Enterprises (Loan, Leasing, Securities) [A vállalkozások tipikus külső finanszírozási forrásai (hitel, lízing, értékpapírok)]. http://kepzesevolucioja.hu/dmdocuments/4ap/19_ooo1_017_101215.pdf (downloaded on 10.09.2018).

VÉGH RICHÁRD (2016): Growth with the Stock Exchange - ELITE Programme in cooperation with the BSE [Növekedés a tőzsdével - ELITE Program, együttmüködésben a BÉT-tel]. https://www. bet.hu/Kibocsatok/kozepvallalati-szolgaltatasok/ELITE-program/ELITE-program (downloaded on 14.03.2018). 